\title{
PERANCANGAN KONTEN KREATIF BERBASIS MULTIMEDIA UNTUK MENINGKATKAN AWARENESS PROGRAM STUDI DESAIN KOMUNIKASI VISUAL UNIVERSITAS MA CHUNG MELALUI MEDIA SOSIAL INSTAGRAM
}

\author{
Nabila Ramadhani Zulfa ${ }^{1}$, Sultan Arif Rahmadianto ${ }^{2}$, Bintang Pramudya P.P. ${ }^{3}$ \\ Program Studi Desain Komunikasi Visual, Universitas Ma Chung \\ Email : 331710015@student.machung.ac.id, sultan.arif@machung.ac.id, \\ bintang.pramudya@machung.ac.id
}

\begin{abstract}
Abstrak
Media sosial sudah digunakan oleh banyak kalangan di Indonesia. Salah satu media sosial yang sangat banyak digunakan yaitu Instagram. Di Instagram, dapat ditemukan fiturfitur yang mendukung untuk penggunanya seperti feed, instastory, dan IGTV. Instagram dapat membantu Lembaga Pendidikan universitas untuk membagikan informasi seputar universitas apabila informasi tersebut dikemas dengan baik dan menarik sesuai dengan identitas. Oleh karena itu, DKV Ma Chung membutuhkan desain Instagram yang baik dan menarik agar pengguna dan pengikut Instagram DKV Ma Chung dapat mengetahui informasi tentang program studi secara lengkap. Penggunaan metode perancangan komunikasi model Sanyoto sangat berhubungan dengan perancangan Konten Kreatif Berbasis Multimedia Pengenalan Progrfam Studi DKV Ma Chung pada Media Sosial karena terbentuk dari tiga aspek yang menjadi panduannya, yaitu aspek media, aspek kreatif, dan aspek tata desain atau visual. Luaran dari perancangan yaitu desain feed Instagram, filter Instagram dan video IGTV. Kesimpulan dari perancangan konten Instagram yaitu Instagram DKV Ma Chung dapat menjadi pusat informasi mengenai keunggulan-keunggulan program studi DKV Ma Chung. Terdapat pula media pendukung berupa merchandise mug, keychain, totebag dan topi.
\end{abstract}

Kata kunci : Media Sosial, DKV Ma Chung, Instagram

\begin{abstract}
Social media has been used by many people in Indonesia. One of the most widely used social media is Instagram. On Instagram, you can find features that support users such as feeds, stories, and IGTV. Instagram can help university educational institutions share information about universities if the information is packaged well and attractively according to identity. Therefore, DKV Ma Chung needs a good and attractive Instagram design so that users and Instagram followers of DKV Ma Chung can find out complete information about the study program. The use of the Sanyoto model of communication design method is closely related to the design of Multimedia-Based Creative Content Introduction to Ma Chung's Visual Communication Design Study Program on Social Media
\end{abstract}

because it is formed from three aspects that serve as guidelines, namely media aspects, creative aspects, and

aspects of design or visual management. The outputs of the design are Instagram feed design, Instagram filters and
IGTV videos. The conclusion from the design of Instagram content is that Ma Chung's DKV Instagram can be a center of information about the advantages of Ma Chung's DKV study program. There are also supporting media in the form of merchandise mugs, keychains, tote bags and hats.

Keywords : Social Media, Ma Chung DKV, Instagram

\section{PENDAHULUAN}

Media sosial menjadi salah satu media penghubung antar manusia yang sangat tidak asing untuk saat ini. Setiap orang di dunia ini setidaknya mempunyai satu media sosial untuk saling membagikan sesuatu, entah itu pengalaman, hal-hal menarik, kegemaran hingga bisnis yang sedang ditekuni. Pada jaman dulu, media sosial hanya berupa bentuk fisik seperti koran, surat, brosur, dll. Seseorang hanya dapat menerima informasi apabila ada pihak lain yang mengantarkan seperti pengantar koran yang setiap pagi mengunjungi rumah-rumah, tukang pos yang setiap hari mengantarkan surat, hingga reporter yang setiap hari membacakan berita, terdengar cukup pasif.

Seiring berjalannya waktu, media sosial semakin beragam bentuknya. Orang-orang mulai dengan mudah mendapatkan informasi yang mereka cari. Awal mula media sosial hanya sebatas itu saja. Media sosial hanya sebuah wadah di internet untuk menampung sedikit identitas dan berkomunikasi dengan sesame pengguna media sosial. Tapi untuk saat ini, media sosial sudah sangat banyak jenisnya, mulai hanya untuk berbagi foto, berbagi video, berbagi quotes, hingga berbagi informasi.

Hanya dengan satu smart phone dimana satu alat tersebut dapat menghubungkan satu orang dengan orang lainnya dengan jumlah yang tak terhingga. Media sosial mengajak siapa saja yang tertarik untuk berartisipasi dengan memberi feedback secara terbuka, memberi komentar, serta membagi informasi dalam waktu yang cepat dan tak terbatas. Tidak dapat dipungkiri bahwa media sosial mempunyai pengaruh yang besar dalam kehidupan seseorang. Seseorang yang awalnya kecil bisa menjadi besar dengan media sosial, atau sebaliknya. Bagi masyarakat khususnya kalangan remaja, media sosial sudah menjadi candu yang membuat penggunanya tiada hari tanpa membuka media sosial.

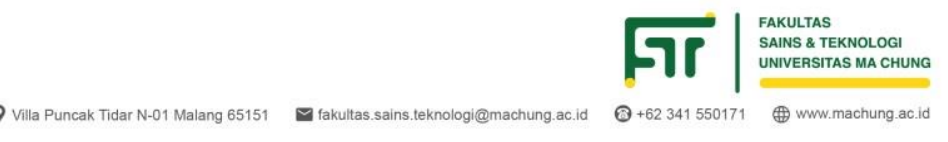


Metode promosi suatu produk atau jasa dengan menggunakan media digital. Dalam dunia bisnis, marketing memiliki peran yang cukup krusial. Strategi pemasaran yang tepat tentu akan berpengaruh positif terhadap kemajuan bisnis itu sendiri. Salah satu metode pemasaran yang cukup gencar dilakukan dalam satu dekade terakhir adalah digital marketing.

Konten yang kreatif adalah salah satu alasan mengapa seseorang bisa berjam-jam memainkan media sosial. Fitur yang cukup banyak dimedia sosial dapat dimanfaatkan sebagai ladang kreatifitas, tapi tak hanya itu, bahkan pemasaran dan periklanan lebih kencang di media sosial dari pada televisi untuk saat ini. Pemasaran dan bentuk iklannya pun harus kreatif dan menarik.

Konten daripada media sosial sendiri cukup beragam, mulai dari hanya untuk sekedar informasi hingga untuk kepentingan komersil. Jika visual tersebut kurang menarik atau tidak sesuai dengan brief, maka yang terjadi adalah engangement media sosial tidak naik atau bahkan menurun. Sudah banyak pelaku bisnis di Indonesia yang sadar akan pentingnya memanajemen konten dan visual dimedia sosial untuk kepentingan promosi. Oleh karena itu, Di Indonesia atau bahkan di dunia, persaingan konten untuk pemasaran di media sosial cukup sengit. Daya saing perusahaan sudah tidak ditentukan lagi oleh ukuran, negara asal, atau sejarah mereka (Kotler, dkk 2019: 7)

Media sosial yang digunakan untuk mempromosikan sebuah produk juga sangat beragam, mulai dari Instagram, Twitter hingga Facebook. Dari sekian banyak jenis media sosial pasti ada satu yang pengaruhnya cukup besar karena banyaknya pengguna dari aplikasi tersebut. Menurut (Nadhiroh, 2019 : 88) dalam Jurnal "Pengaruh Social Media Marketing Terhadap Brand Awareness Pada Followers Instagram Warunk Upnormal", salah satu media sosial yang dominan dan banyak disukai serta dimanfaatkan oleh masyarakat Indonesia terutama di kalangan remaja ialah media sosial Instagram. Instagram merupakan aplikasi media sosial yang mendominasi audio-visual dengan durasi yang tidak terbatas.

DKV Ma Chung adalah salah satu program studi S1 di Universitas Ma Chung yang membutuhkan sebuah perancangan untuk meningkatkan popularitas dan minat siswa pada program studi tersebut. DKV Ma Chung berdiri pada tahun 2007 di Kota Malang. Meski dibilang cukup muda, DKV Ma Chung mendapatkan akreditasi B. DKV Ma Chung memiliki 2 peminatan yaitu 2D dan 3D, beberapa diantaranya yaitu, Animasi, Branding, Fotografi, Videografi dan lain sebagainya.

Berdasarkan hal-hal tersebut, penulis memutuskan untuk melakukan perancangan konten kreatif berbasis multimedia pengenalan Program Studi DKV Ma Chung pada media sosial. Agar DKV Ma Chung dapat dikenal lebih dalam dengan citra yang baik, juga masyarakat luas dapat mengetahui prestasi-prestasi yang telah dicapai oleh para mahasiswa DKV Ma Chung, sehingga DKV Ma Chung dapat menjadi contoh bagi Prodi DKV di Universitas lain juga menjadi pilihan bagi siswa-siswa SMA/SMK/MA Se-derajat yang akan memasuki dunia DKV.

\section{Metode Perancangan}

Metode perancangan yang digunakan dalam perancangan Konten Kreatif Berbasis Multimedia Pengenalan Program Studi DKV Ma Chung pada Media Sosial menggunakan metode perancangan Kualititatif dengan komunikasi model Sanyoto. Metode perancangan ini didasari pada aspek desain komunikasi visual yang mengacu pada hasil akhir berupa keuntungan materiil (komersil) maupun nonmaterial (sosial). Penggunaan metode perancangan komunikasi model Sanyoto sangat berhubungan dengan perancangan Konten Kreatif Berbasis Multimedia Pengenalan Progrfam Studi DKV Ma Chung pada Media Sosial karena terbentuk dari tiga aspek yang menjadi panduannya, yaitu aspek media, aspek kreatif, dan aspek tata desain atau visual. Ketiga aspek tersebut disebut sebagai paduan periklanan yang tidak bisa dipisahkan agar menghasilkan sebuah karya yang efektifefisien dan komunikatif-persuasif (Sanyoto; 2006: pp.3639).

Aspek media merupakan wadah atau alat untuk menjangkau khalayak sasaran (target audience). Aspek media mewadahi isi pesan untuk dibawa ke hadapan target audience. Isi yang ada di dalam media tersebut disebut kreatif. Aspek kreatif merupakan isi pesan yang diwadahi media. Aspek kreatif bertugas mempengaruhi target audience untuk bertindak sesuai keinginan pemberi pesan. Aspek tata desain adalah tata rupa, tata artistik, dan komposisi dari unsur-unsur desain komunikasi visual yang berwujud bentuk-bentuk kreatif verbal-visual yang diprogram pada program kreatif berupa penulisan teks dan pengarahan visual. Aspek tata desain kemudian disusun atas dasar kaidah-kaidah tata desain berupa prinsip dasar untuk menyenangkan target audience (Sanyoto; 2006: pp.36-39).

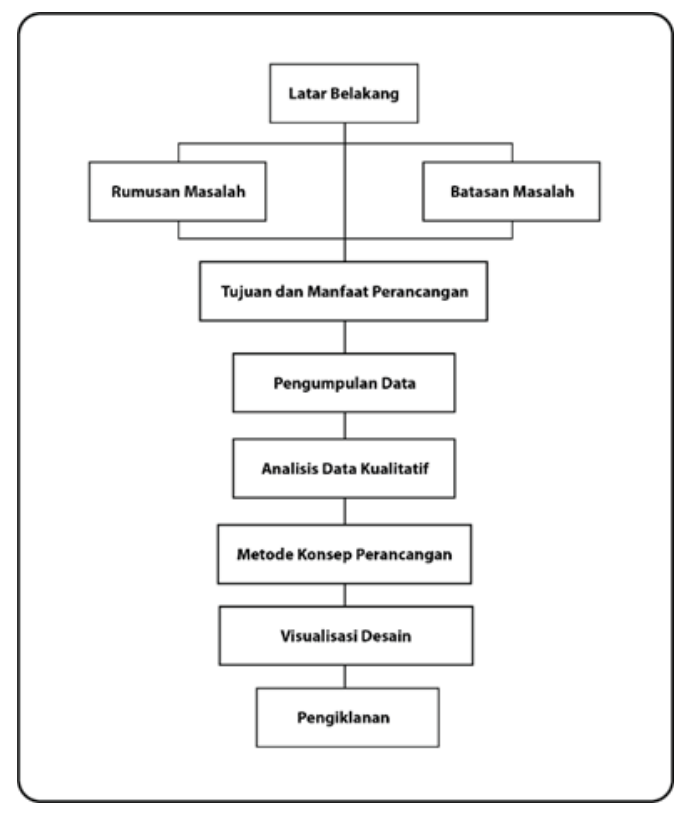

Gambar 1. Bagan Alur Perancangan 


\section{Metode Konsep Perancangan}

Dalam perancangan yang dilakukan penulis, terdapat metode konsep perancangan sebagai berikut : menggunakan metode konsep perencanaan kreatif. Konsep perencanaan kreatif merupakan konsep untuk menciptakan hal baru, dalam konteks ini adalah pesan. Pesan kreatif mencakup pesan secara verbal dan visual secara desain komunikasi visual (Sanyoto; 2006: pp.6162). Dalam perencanaan konsep kreatif, terdapat beberapa komponen, yaitu:

Tujuan kreatif merupakan pengaruh atau pesan yang ingin ditanamkan pada target audience melalui produk atau iklan yang dirancang. Pengaruh dari tujuan kreatif dapat berupa pesan yang hendak disampaikan ataupun respon yang diinginkan terjadi pada target audience terhadap perancangan yang dibuat nantinya. Dalam perancangan Tugas Akhir ini akan digunakan tujuan kreatif produk rintisan yang berfokus pada tahap pengenalan dan pemahaman (awareness and knowledge) dari perancangan yang dihasilkan (Sanyoto; 2006: pp.7880).

Strategi kreatif adalah kebijakan-kebijakan yang dilakukan terhadap paduan kreatif (isi dan bentuk pesan), yang disusun berdasarkan target audience karena pada dasarnya target audience yang menentukan isi dan bentuk dari suatu pesan yang akan disampaikan. Titik berat dalam strategi kreatif adalah menentukan target audience kreatif dan menetapkan isi serta bentuk pesan yang akan disampaikan kepada target audience untuk memenuhi kebutuhan tujuan kreatif. Isi pesan merupakan ide-ide yang akan disampaikan kepada target audience, sedangkan bentuk pesan adalah visualiasi dari isi pesan yang dikemas agar menarik minat target audience (Sanyoto; 2006: pp.82-83).

Proses program kreatif merupakan realisasi dari strategi kreatif dengan melakukan pendataan kebutuhan elemen-elemen desain komunikasi visual dalam suatu perancangan kreatif. Pendataan tersebut disebut sebagai Petunjuk Umum Kreatif (Creative Guideline). Pada bagian ini dilakukan pendataan ulang terhadap pokokpokok kreatif dari pesan kreatif (isi dan badan pesan) yang digunakan sebagai dasar umum dalam perancangan. Hal -hal tersebut bisa berupa: headline (beberapa kemungkinan judul dan tema); body copy (pokok rancangan tekstual yang akan digunakan pada media kreatif); slogan; logo, merek, alamat, atau nama sponsor; bentuk-bentuk ilustrasi; bentuk huruf utama; hingga warna atau tone yang digunakan pada perancangan nantinya (Sanyoto; 2006: pp.105-106).

Biaya kreatif merupakan segala biaya yang dikeluarkan dalam perencanaan dan perancangan yang dilakukan. Biaya kreatif menyangkut biaya produksi dan penggandaan produk yang dihasilkan seperti biaya cetak dan biaya-biaya lain yang dibutuhkan agar perancangan dapat selesai secara optimal (Sanyoto; 2006: p.107). dalam perancangan Konten Kreatif berbasis Multimedia Pengenalan DKV Ma Chung pada Media Sosial ini biaya kreatif yang dimaksud adalah biaya untuk pengiklanan unggahan di Instagram.

Visualisasi desain merupakan langkah untuk memberikan daya tarik pada suatu produk agar dapat memikat target audience. Dalam prosesnya, visualisasi desain memiliki beberapa tahapan, yaitu: idea layout (thumbnail), rough layout (tight tissue), comprehensive layout (execution), dan desain final. Idea layout merupakan coretan-coretan yang berisi gagasan sesuai deskripsi kreatif yang telah dibuat dengan mengacu pada keilmuan desain komunikasi visual. Umumnya idea layout berukuran lebih kecil dari desain aslinya sehingga sering disebut thumbnail. Rough layout merupakan thumbnail yang disempurnakan dengan cara dirapikan dan dibuat menggunakan proporsi yang lebih baik. Biasanya rough layout akan dibuat rangkap dengan dengan mengaplikasikan beberapa gaya atau warna berbeda yang kemudian dipilih untuk menjadi comprehensive layout.

Comprehensive layout merupakan pilihan layout kasar yang disempurnakan. Comprehensive layout memuat sketsa gambar secara detil mengenai pesan yang akan disampaikan sebelumnya, baik dari isi pesan hingga suasana yang akan dibawa. Setelah itu, hasil dari comprehensive layout akan menjadi hasil akhir perancangan yaitu desain final (Sanyoto; 2006: pp.122127).

Target dari perancangan Konten Kreatif berbasis Multimedia pengenalan DKV Ma Chung pada Media Sosial adalah:
a. Jenis Kelamin : Pria dan Wanita
b. Usia : $15-25$ tahun
c. Pekerjaan : Akademisi
d. Minat : Mengenal DKV Ma Chung lebih dalam dan tertarikl melanjutkan studi di DKV Ma Chung.
e. Wilayah : Pulau Jawa

Tabel 1. Indikator Capaian

\begin{tabular}{|c|c|c|c|c|}
\hline $\begin{array}{l}\text { No } \\
.\end{array}$ & $\begin{array}{l}\text { Jenis } \\
\text { Luaran }\end{array}$ & $\begin{array}{l}\text { Kategori } \\
\text { Luaran }\end{array}$ & $\begin{array}{l}\text { Sub } \\
\text { Kategori } \\
\text { Luaran }\end{array}$ & $\begin{array}{l}\text { Indikator } \\
\text { Capaian } \\
\text { (Spesifikas i } \\
\text { Teknis) }\end{array}$ \\
\hline 1. & Desain & $\begin{array}{l}\text { Desain } \\
\text { Unggaha } \mathrm{n} \\
\text { k untu } \\
\text { Instagra m }\end{array}$ & Poster & \begin{tabular}{l} 
Desain feed \\
instagram \\
setidaknya \\
sebanyak 40 \\
\multicolumn{1}{c}{ des } \\
ain feed \\
dengan \\
ukuran \\
square $(1 \times 1)$
\end{tabular} \\
\hline
\end{tabular}




\begin{tabular}{|c|c|c|c|c|}
\hline 2. & $\begin{array}{l}\text { Fotograf } \\
\text { i }\end{array}$ & $\begin{array}{l}\text { Lanskap, } \\
\text { Potrait, } \\
\text { Human } \\
\text { Interest }\end{array}$ & $\begin{array}{l}\text { Foto } \\
\text { pendukun } \\
\text { g desain }\end{array}$ & $\begin{array}{l}\text { Foto di spot } \\
\text { tempat } \\
\text { kebanyaka n } \\
\text { mahasiswa } \\
\text { DKV Ma } \\
\text { Chung } \\
\text { berada } \\
\text { (Kaligrafi, } \\
\text { Ruang } \\
\text { Dosen, SC, } \\
\text { dll) }\end{array}$ \\
\hline
\end{tabular}

\begin{tabular}{|c|c|c|c|c|}
\hline 4. & Videografi & $\begin{array}{l}\text { Cinematic } \\
\text { Video, } \\
\text { Telling } \\
\text { story } \\
\text { video }\end{array}$ & $\begin{array}{l}\text { Short } \\
\text { Video } \\
\text { untuk } \\
\text { IGTV }\end{array}$ & $\begin{array}{l}\text { Video } \\
\text { pendek } \\
\text { durasi 1-2 } \\
\text { menit sesuai } \\
\text { dengan } \\
\text { konten yang } \\
\text { sudah di } \\
\text { setujui oleh } \\
\text { Kaprodi } \\
\text { DKV Ma } \\
\text { Chung. 10 } \\
\text { IGTV } \\
\text { tentang } \\
\text { DKV Ma } \\
\text { Chung. }\end{array}$ \\
\hline 5. & $\begin{array}{l}\text { Insight } \\
\text { Instagram }\end{array}$ & - & - & $\begin{array}{l}\text { Seberapa } \\
\text { banyak } \\
\text { pencapaian } \\
\text { Instagram } \\
\text { dalan } \\
\text { menjangkau } \\
\text { pengikut } \\
\text { baru Media } \\
\text { Sosial } \\
\text { Instagram. }\end{array}$ \\
\hline 6. & $\begin{array}{l}\text { Filter } \\
\text { Instagram }\end{array}$ & $\begin{array}{l}\text { Fun, } \\
\text { Aesthetic }\end{array}$ & - & $\begin{array}{l}1 \text { Filter } \\
\text { Instagram } \\
\text { dengan } \\
\text { konsep fun } \\
\text { dan } 1 \text { filter } \\
\text { Instagram } \\
\text { dengan } \\
\text { konsep } \\
\text { aesthetic. }\end{array}$ \\
\hline 7. & Laporan & - & - & $\begin{array}{l}\text { Draft } \\
\text { Laporan } \\
\text { Tugas } \\
\text { Akhir }\end{array}$ \\
\hline
\end{tabular}

\section{Konsep Perancangan}

Dari data yang sudah dianalisis, dibutuhkan sintetis konsep untuk menyusun konten kreatif pada Instagram DKV Ma Chung. Konten Kreatif ini akan disusun dengan menggunakan desain brief yang sudah ditentukan yaitu sesuai dengan warna dan style design logo DKV Ma Chung. Konten kreatif disusun dengan data yang sudah didapat dan dianalisis oleh penulis.

Konten kreatif pada Instagram DKV Ma Chung dapat membantu melengkapi informasi yang selama ini belum diketahui oleh pengikut Instagram DKV Ma Chung dan dapat mengundang pengikut baru karena kebutuhan pengetahuan informasi tentang DKV Ma Chung. Profil DKV Ma Chung dapat membantu menambah informasi kaum awam yang belum mengetahui tentang DKV Ma Chung, Peminatan Jurusan juga diangkat sebagai konten guna untuk mempertegas dan memperjelas apa saja yang ada di DKV Ma Chung, Spot tempat diangkat sebagai konten guna untuk memberitahu pada pengikut DKV Ma Chung bagaimana suasana perkuliahan di DKV Ma Chung, Karya mahasiswa diangkat menjadi konten guna untuk memberi tahu kepada pengikut seperti apa hasil karya setelah menjadi mahasiswa di DKV Ma Chung, terakhir opini mahasiswa di angkat menjadi konten guna untuk menyuarakan pendapat, saran, dan pengalaman mahasiswa DKV Ma Chung.

Strategi kreatif adalah kebijakan-kebijakan yang dilakukan terhadap paduan kreatif (isi dan bentuk pesan), yang disusun berdasarkan target audience karena pada dasarnya target audience yang menentukan isi dan bentuk dari suatu pesan yang akan disampaikan. Titik berat dalam strategi kreatif adalah menentukan target audience kreatif dan menetapkan isi serta bentuk pesan yang akan disampaikan kepada target audience untuk memenuhi kebutuhan tujuan kreatif. Isi pesan merupakan ide-ide yang akan disampaikan kepada target audience, sedangkan bentuk pesan adalah visualiasi dari isi pesan yang dikemas agar menarik minat target audience (Sanyoto; 2006: pp.82-83).

Strategi kreatif yang diterapkan pada perancangan konten kreatif Instagram DKV Ma Chung yaitu dengan menerapkan informasi keseluruhan tentang DKV Ma Chung kepada semua fitur yang ada di Instagram(Feed, IGTV, Reels dan Filter), lalu diterapkan juga Instagram Ads sebagai marketing atau promosi Program Studi DKV Ma Chung.

Data yang digunakan dalam perancangan ini dikumpulkan secara kualitatif kepada informan objek perancangan yaitu Kepala Program Studi DKV Ma Chung, Mahasiswa DKV Ma Chung, dan perwakilan siswa SMA/SMK/MA. Pengumpulan data dalam perancangan ini menggunakan pengumpulan data penelitian kualitatif didapatkan melalui beberapa cara, yaitu wawancara mendalam, observasi partisipan, dan dokumentasi (Prastowo; 2011: pp.212-230).

Wawancara mendalam adalah proses memperoleh keterangan untuk tujuan penelitian dengan cara tanya jawab sambil bertatap muka atau melalui media sosial antara pewawancara dan informan yang terlibat dalam suatu kehidupan sosial. Wawancara mendalam dilakukan bersama informan dalam waktu tertentu secara bertahap di lokasi penelitian. Wawancara mendalam dilakukan secara tidak formal dan tidak sistematik 
sehingga data yang didapat bisa berupa data verbal dan non-verbal. Oleh karena itu, perlu adanya persiapan sebelum wawancara dilakukan seperti persiapan pertanyaan wawancara, persiapan pengetahuan yang cukup tentang hal yang karena itu, perlu adanya persiapan sebelum wawancara dilakukan seperti persiapan pertanyaan wawancara, persiapan pengetahuan yang cukup tentang hal yang ditanyakan, buku catatan ataupun tape recorder untuk memudahkan proses wawancara nantinya (Prastowo, 2011).

Wawancara dilakukan secara daring kepada narasumber bersamaan dengan menganalisa media sosial yang nantinya akan digunakan sebagai konten kreatif Instagram. Wawancara dilakukan dalam bentuk googleform sehingga penulis dapat mengetahui konten seperti apa yang menarik dan penting untuk diangkat kedalam media sosial Instagram.

Observasi adalah teknik pengumpulan data melalui pengamatan terhadap objek pengamatan dengan langsung hidup bersama, merasakan, serta berada dalam aktivitas kehidupan objek pengamatan. Kegiatan observasi memiliki tingkat akurasi data yang baik tetapi memakan waktu yang lama. Hal-hal yang dapat diperhatikan saat melakukan observasi adalah: pemahaman terhadap objek pengamatan; pencatatan data yang tidak mengganggu objek pengamatan; menjaga hubungan baik dengan objek pengamatan; serta durasi dan luas lingkup pengamatan yang dilakukan (Prastowo; 2011: pp.220-222).

Observasi dilakukan dengan mengunjungi langsung objek perancangan dan memastikan hasil wawancara tersebut benar adanya. Serta melakukan pengamatan kegiatan, tempat dan perilaku sesuai dengan hasil wawancara yang telah dilakukan.

Dokumentasi merupakan kegiatan pengumpulan informasi yang didapat dari dokumen, yakni peninggalan tertulis, arsip-arsip, akata ijazah, rapor, peraturan perundang-undangan, buku harian, surat pribadi, catatan biografi dan lain-lain yang memiliki keterkaitan dengan masalah yang diteliti. Dokumentasi pada dasarnya berupa rekaman yang bersifat tertulis atau film dan berisi peristiwa yang telah berlalu. Dokumentasi memungkinkan data yang didapat dari wawancara ataupun observasi menjadi lebih kredibel dengan bukti fisik yang telah dikumpulkan (Prastowo; 2011: pp.226227).

Dokumentasi dilakukan dengan mengunjungi langsung objek perancangan dan mengambil gambar sesuai dengan hasil wawancara dan observasi yang sudah dilakukan. Dokumentasi nantinya akan dijadikan sebagai salah satu media pendukung perancangan konten kreatif pada media sosial Instagram.

Data-data yang telah dikumpulkan tersebut diproses menggunakan identifikasi data agar mendapat sistematika yang baik untuk perancangan (Sanyoto; 2006: 42-43). Identifikasi data yang dilakukan meliputi data perusahaan dan data produk yang bersangkutan. Identifikasi data dilakukan pada data perusahaan yang meliputi data pengelola usaha, seperti nama, alamat, pemilik, profil perusahaan, dan data lain dari perusahaan yang dapat mendukung perancangan nantinya (Sanyoto; 2006: p.43). Kemudian, identifikasi data produk yang dilakukan meliputi jenis produk, bahan baku, merek perusahaan, logo perusahaan, kemasan, harga, keunggulan produk, potensi perkembangan, dan lain-lain (Sanyoto; 2006: p.43). Data-data perusahaan dan produk kemudian disusun serta dikelompokkan untuk dilakukan analisis pemasaran objek yang bersangkuat. Data dan analisis pemasaran dalam perancangan tersebut meliputi (Sanyoto; 2006: p.43):

Data posisi pasar meliputi besar omset sebuah usaha, distribusi pemasaran, corporate image produk atau perusahaan di kalangan target audience, dan konsentrasi pemasaran (lokasi pemasaran).

Potensi pasar meliputi data pola pembeliaan, masalah yang dihadapi dalam pemasaran, dan target yang ingin dicapai.

Segmentasi pemasaran meliputi kedudukan produk sebagai bahan konsumsi, daya jangkau konsumen terhadap harga produk, hingga target audience dari produk atau brand.

Promosi yang telah dilakukan meliputi publicity, personal selling, sales promotion adveretising).

Pesaing yang dimaksud adalah competitor produk sejenis, harga, pemasaran, target audience, kegiatan dan bentuk promosi.

Dalam perancangan ini dijabarkan informasi tentang DKV Ma Chung secara mendetail, mulai dari profil hingga karya-karya mahasiswa. Dengan harapan agar masyarakat luas lebih mengenal DKV Ma Chung dan memandang DKV Ma Chung sebagai program studi yang Fun Damental sesuai dengan filosofi logo yang sudah ada. Untuk mewujudkan hal tersebut maka dari itu dirancanglah konten kreatif yang visualnya sesuai dengan brief logo DKV Ma Chung. Penggunaan warna dan font yang tidak diubah dan tetap sesuai.

Instagram dengan visual yang menarik dan informatif dapat menarik perhatian. Oleh karena itu Instagram DKV Ma Chung dirancang dengan desain yang sesuai brief dan copywriting yang menarik. Penggunaan kata dan kalimat yang tepat dapat sangat berpengaruh pada cara membaca dan sudut pandang pengikut akun Instagram.

Selanjutnya perancangan video untuk fitur IGTV dan Reels. Video dirancang dengan konten yang didatangkan langsung dari mahasiswa DKV Ma Chung agar terkesan menjadi testimoni seperti apa luaran mahasiswa DKV Ma Chung. Video berdurasi tidak terlalu panjang(30 detik - 1 menit) tapi cukup mengedukasi dan dapat membagikan pengalaman yang cukup bermanfaat bagi pengikut Instagram

Selanjutnya filter Instagram digunakan sebagai penghibur di akun Instagram DKV Ma Chung.

Mengingat filter adalah fitur yang paling terkenal dan unggul bagi media sosial Instagram itu sendiri. Genre filter selalu berubah sesuai dengan perkembangan style. Untuk saat ini filter Instagram sedang marak dengan genre 
y2k 90's. dimana genre tersebut akan digunakan dan diterapkan di akun Instagram DKV Ma Chung. Selanjutnya yaitu pengiklanan kiriman di Instagram DKV Ma Chung. Strategi untuk menarik pengikut baru pada akun Instagram DKV Ma Chung yaitu dengan mengiklankan postingan penting dengan menggunakan layanan fitur Instagram yaitu Instagram Ads. Insight yang sesuai dan tinggi dapat mempertahankan kualitas dan kuantitas daripada akun Instagram itu sendiri.

Proses program kreatif merupakan realisasi dari strategi kreatif dengan melakukan pendataan kebutuhan elemenelemen desain komunikasi visual dalam suatu perancangan kreatif. Berikut program kreatif dari perancangan konten kreatif:

Instagram Feed

Instagram feed DKV Ma Chung berisikan konten tentang profil DKV Ma Chung, peminatan jurusan, spot tempat akademis dan non-akademis, karya mahasiswa, dan opini mahasiswa. Instagram feed diisi dengan desain vector, foto/gambar, informasi dalam bentuk kata maupun paragraph, logo, dan contact DKV Ma Chung.

IGTV

IGTV dan Reels di Instagram DKV Ma Chung berkonsep tentang peminatan jurusan di DKV Ma Chung. Video IGTV berdurasi lebih dari 1 menit, sedangkan Reels berdurasi maksimal 30 detik. Konten untuk IGTV dan Reels bertujuan untuk memberi informasi dengan footage narasumber yang menceritakan pengalamannya diselingi dengan footage saat praktik pembuatan karya. Video diberi opening, keterangan dan penutup menggunakan motion graphic. Instagram Filter

Instagram filter pada akun Instagram DKV Ma Chung dirancang dengan 2 genre yang berbeda. Yang pertama menggunakan style $\mathrm{y} 2 \mathrm{k}$ dengan beberapa background yang dapat berganti-ganti saat sekali klik kamera maupun saat record. Desain background dirancang sesuai dengan peminatan jurusan yang ada di DKV Ma Chung seperti Branding, Animation, Games, Comis, Illustration, dan photography. Setiap background didesain menggunakan pattern yang berisikan elemen icon dari setiap peminatan jurusan. Lalu yang kedua dengan style cinematic tone. Cinematic tone yang digunakan bernuansa dingin dan dramatis seperti colour grading yang digunakan untuk film.

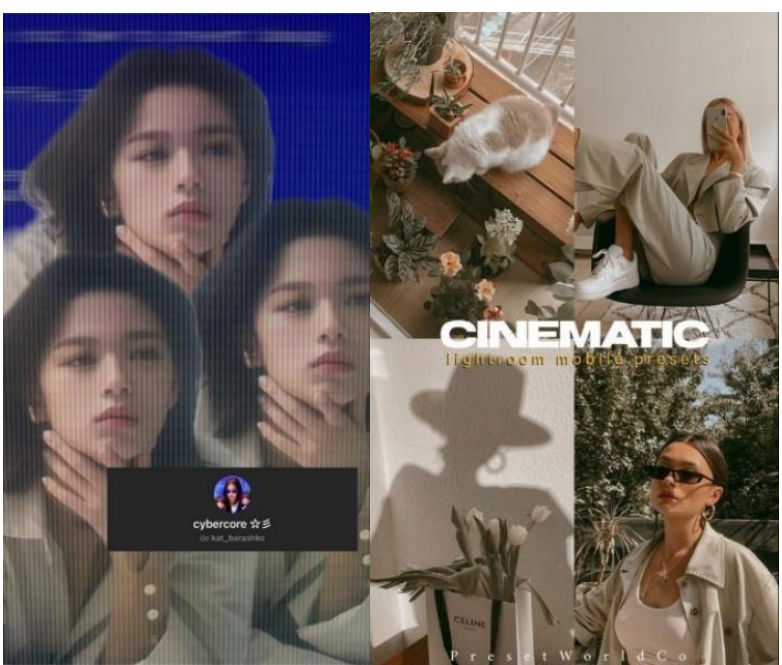

Gambar 2. Contoh genre y2k dan Cinematic Instagram filter

\section{Hasil dan Pembahasan}

Hasil Konten Tekstual

Hasil konten tekstual merupakan konten untuk Instagram yang dirancang berdasarkan hasil pengumpulan data pada DKV Ma Chung. Berikut merupakan konten yang akan diterapkan pada desain Instagram feed:

Berikut tabel konten yang nantinya akan divisualisasi untuk feed Instagram :

Tabel 2. Konten Instagram

\begin{tabular}{|c|c|c|}
\hline No. & Segment & Keterangan \\
\hline 1. & $\begin{array}{c}\text { Tau Gak } \\
\text { Sih? }\end{array}$ & $\begin{array}{l}\text { Konten yang digunakan untuk } \\
\text { memberi informasi kepada } \\
\text { netizen tentang Sejarah, Jurusan, } \\
\text { Events, dan Visi Misi. }\end{array}$ \\
\hline 2. & $\begin{array}{c}\text { Viture } \\
\text { (Visual } \\
\text { Culture) }\end{array}$ & $\begin{array}{l}\text { Konten yang digunakan untuk } \\
\text { memberi informasi kepada } \\
\text { netizen tentang Filosofi Logo } \\
\text { DKV Ma Chung) }\end{array}$ \\
\hline 3. & $\begin{array}{l}\text { Share - } \\
\text { Share }\end{array}$ & $\begin{array}{llr}\text { Konten yang digunakan untuk } \\
\text { memberi informasi } & \text { kepada } \\
\text { netizen tentang } & \text { Karya } & \text { - karya } \\
\text { mahasiswa } & \text { DKV } & \text { Ma } \\
\text { Chung(Repost). } & & \\
\end{array}$ \\
\hline 4. & Where is it? & $\begin{array}{l}\text { Konten yang digunakan untuk } \\
\text { memberi informasi kepada } \\
\text { netizen tentang Spot/tempat } \\
\text { dimana mahasiswa DKV Ma } \\
\text { Chung menghabiskan waktu } \\
\text { (nugas, } \\
\text { praktikum, dll) }\end{array}$ \\
\hline 5. & Promotions & $\begin{array}{l}\text { Konten yang digunakan untuk } \\
\text { memberi informasi kepada } \\
\text { netizen tentang Kapan saja } \\
\text { tanggal-tanggal penting untuk } \\
\text { pendaftaran }\end{array}$ \\
\hline
\end{tabular}




\begin{tabular}{|c|c|l|}
\hline & & $\begin{array}{l}\text { (bersangkutan dengan } \\
\text { Universitas) }\end{array}$ \\
\hline 6. & Quotes & $\begin{array}{l}\text { Konten yang digunakan untuk } \\
\text { memberi informasi kepada } \\
\text { netizen tentang Kutipan kata-kata } \\
\text { atau kalimat motivasi yang sudah } \\
\text { diisi di google form }\end{array}$ \\
\hline
\end{tabular}

Adapun skrip untuk perancangan IGTV dan Reels sebagai berikut :

A. Food Photography di DKV Ma Chung - IGTV

(Sketch)

a. Introducing "Apa sih Food Photography itu?"

b. Introducing 2 "Perkenalan dengan Narasumber"

c. Opening content "Awal mula tertarik dengan Food Photography"

d. Content "Bagaimana mulai mengeksplor"

e. Content 2 "Apa saja yang perlu dipersiapkan"

f. Closing "Tips untuk memulai didunia Food Photography"

g. (Footage)

h. Bumper opening motion graphic

i. Footage (Selingan video narasumber dan practice)

j. Transition (Sesuai segment)

Berikut perancangan untuk Instagram filter :

A. Background Filter

a. Desain 1 (Branding \& Graphic Design)

Element Icon yang berhubungan dengan branding

b. Desain 2 (Animation)

Element Icon yang berhubungan dengan

Animasi

c. Desain 3 (Games \& Digital Media Design)

Element Icon yang berhubungan dengan Games

d. Desain 4 (Comic \& Illustration)

Element Icon yang berhubungan dengan Comic

e. Desain 5 (Photography \& Videography) Element Icon yang berhubungan dengan Foto dan Videografi

\section{Layout of Content}

Berikut layout konten yang nantinya akan disusun pada feed Instagram :

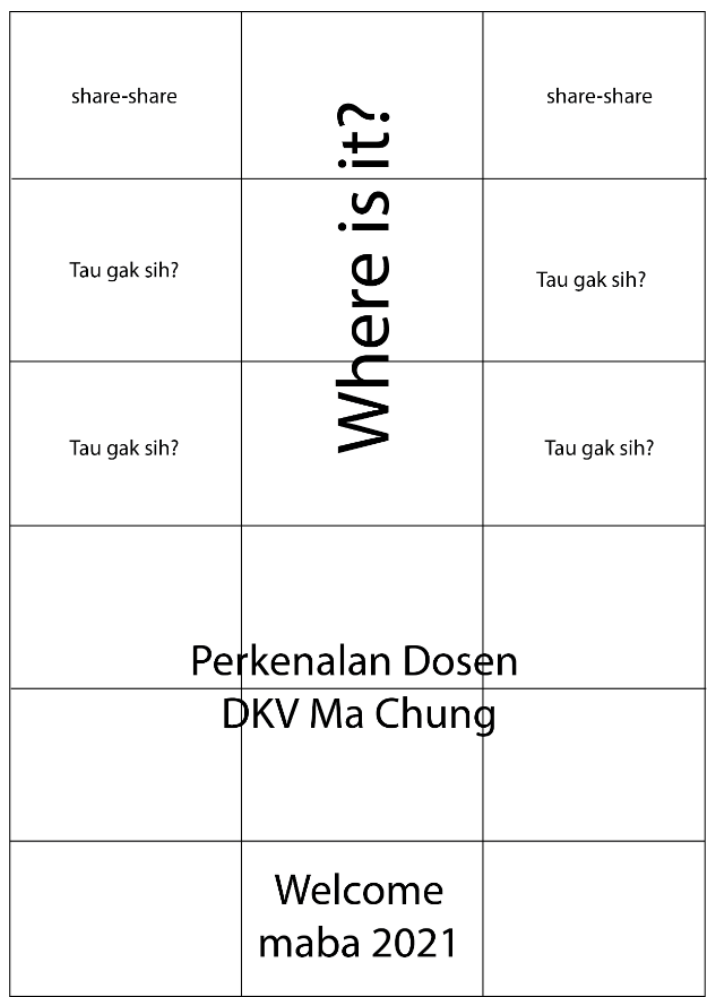

Gambar 3. Layout Feed Instagram

Idea Layout (Thumbnail)

Idea layout atau thumbnail merupakan sektsa atau gambaran awal yang menjadi dasar dalam pembuatan suatu karya. Idea layout dalam perancangan ini dibuat untuk menentukan posisi semua elemen dalam buku. Idea layout berupa gambaran kasar yang dijadikan pedoman. Berikut merupakan contoh idea layout pada perancangan ini:

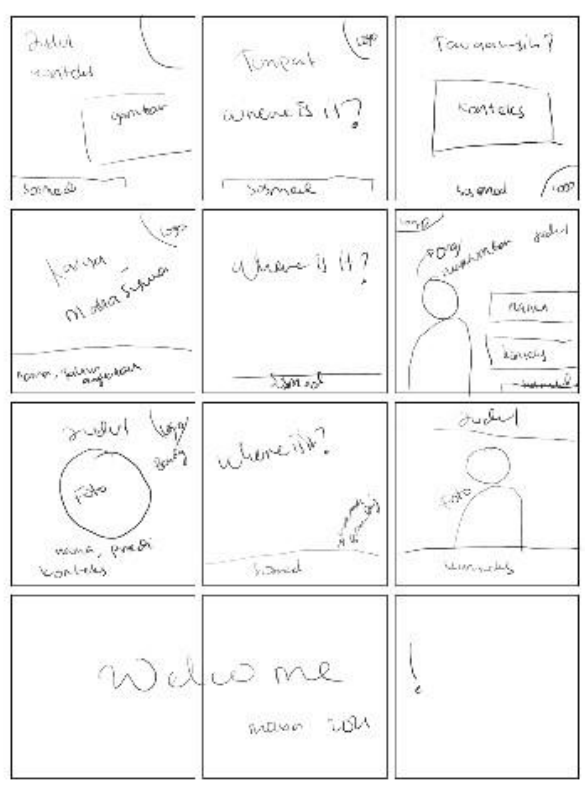

Gambar 4. Rough Layout 1

Rough Layout

Berikut perwakilan rough layout yang akan menjadi pedoman visualisasi desain Instagram feed : 


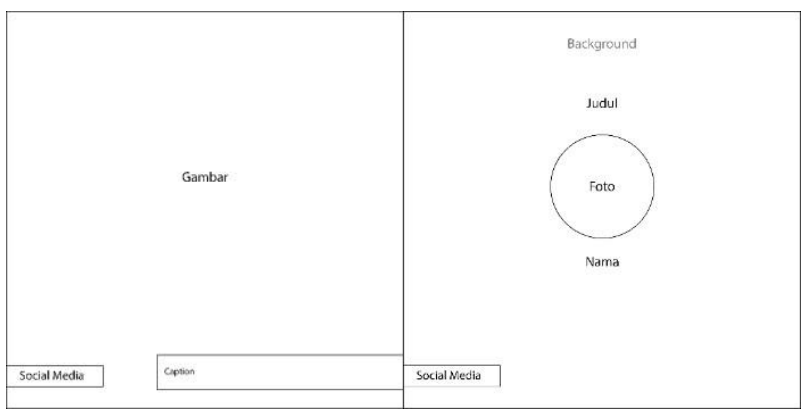

Gambar 5 Rough Layout 1

Comprehensive Layout

Comprehensive layout merupakan visualisasi dari rough layout dengan menggunakan aset-aset visual yang dapatkan dari pengumpulan data sebelumnya. Tahap ini merupakan tahap perwakilan dari seluruh visualisasi konten Instagram Feed DKV Ma Chung. Berikut adalah beberapa contoh dari comprehensive layout dari perancangan ini.
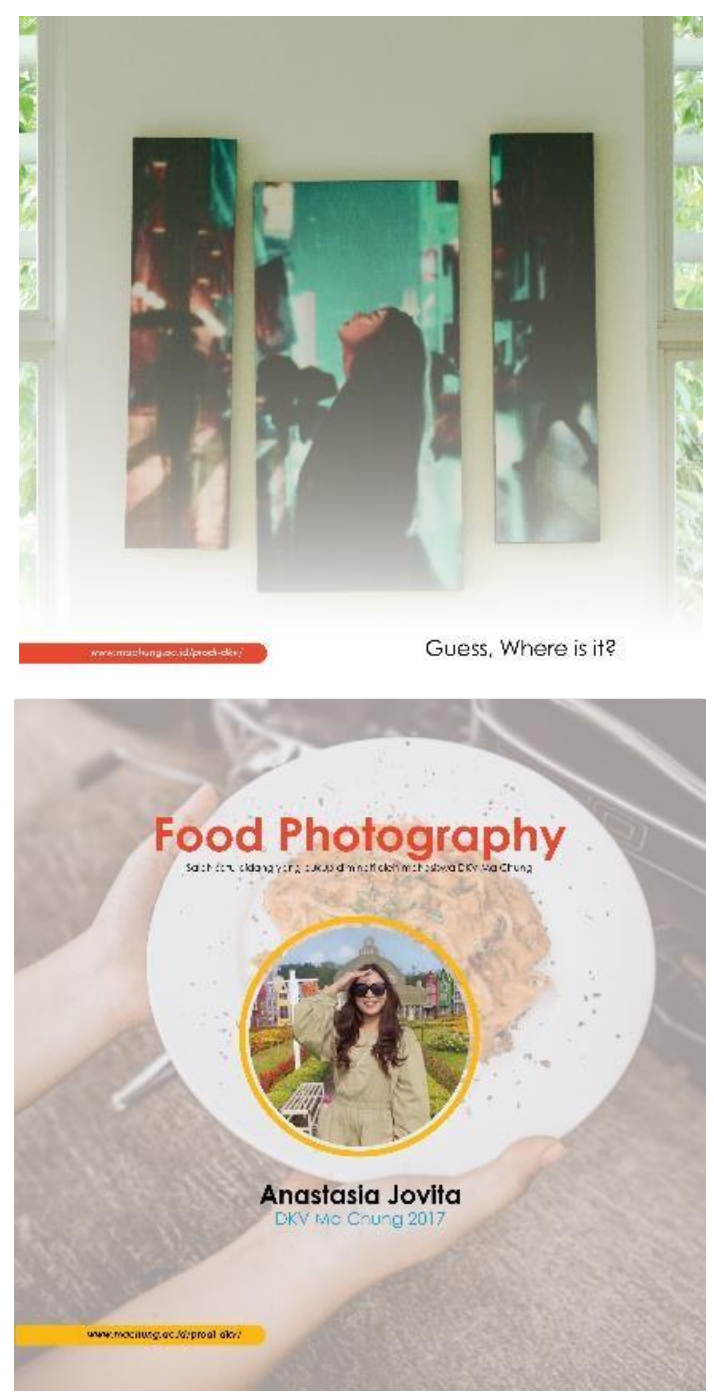

Gambar 6. Comprehensive Layout 1

Desain Final

Desain final merupakan tahapan terakhir dari visualisasi. Hasil dari desain final merupakan bentuk layout yang lengkap dengan segala konten dan elemennya serta siap untuk diposting ke media social Instagram DKV Ma 
Chung. Berikut merupakan desain final dari media utama dalam perancangan Konten Kreatif media social Instagram DKV Ma Chung.
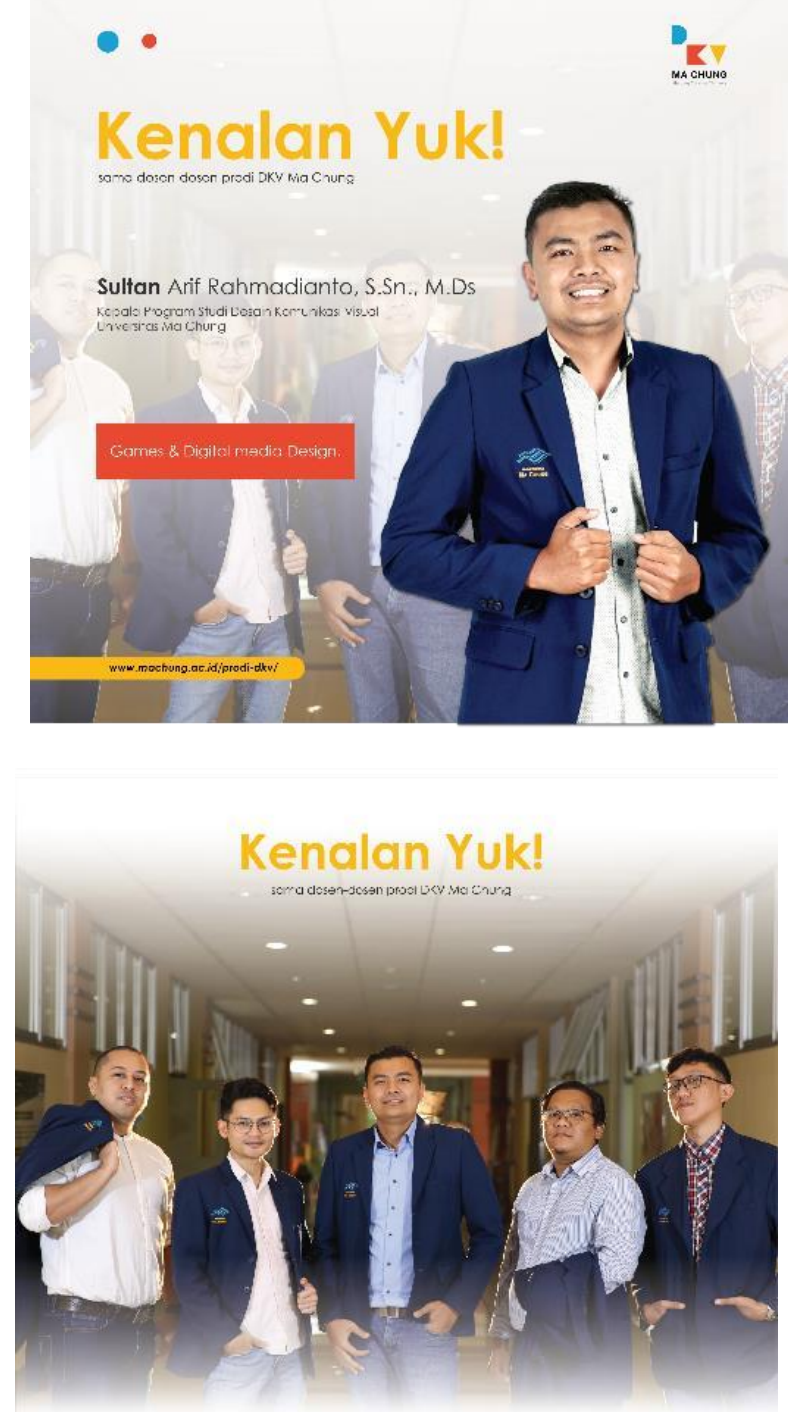

Gambar 8. Desain Feed Final 6

Gambar 7. Desain Feed Final 2

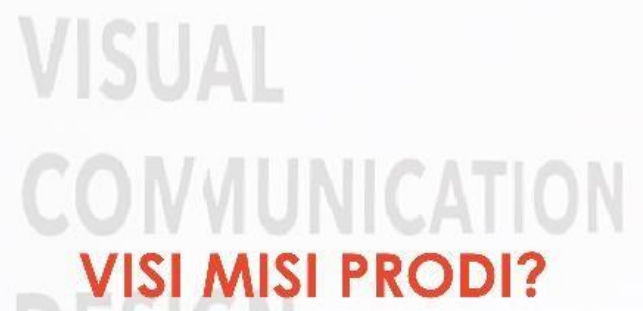

Cari tau yuk, apa aja VISI MISI Program Studi DKV Ma Chung!
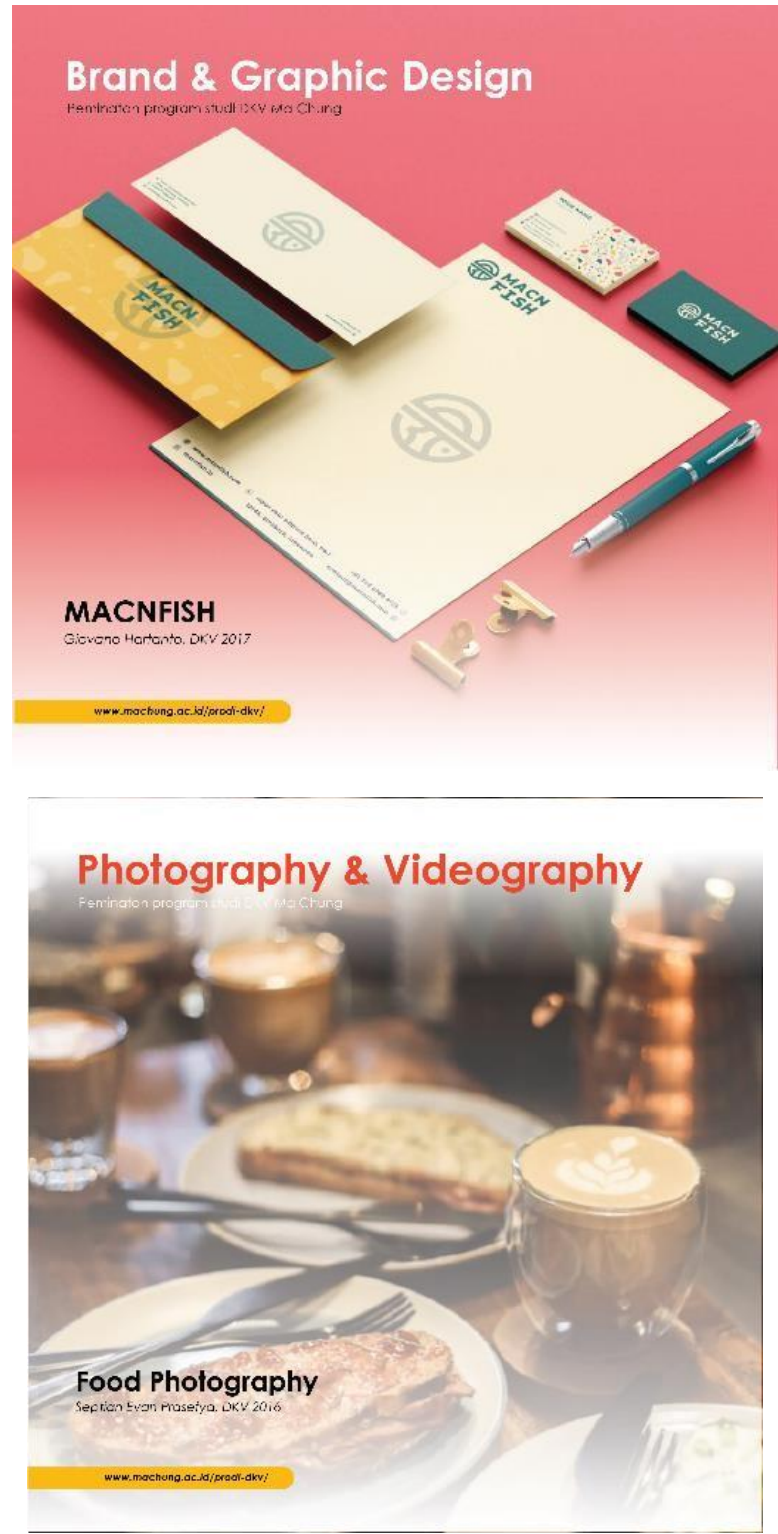


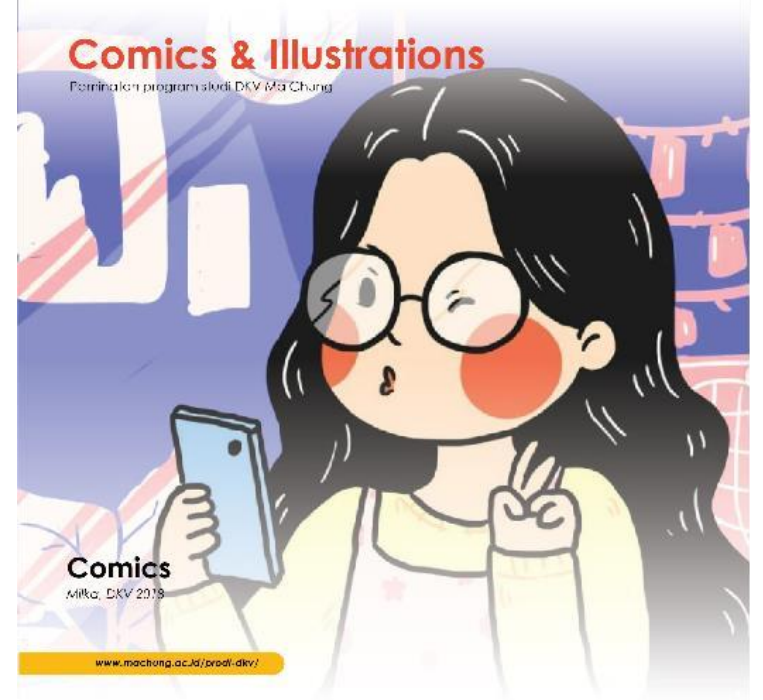

Gambar 9. Desain Feed Final 7

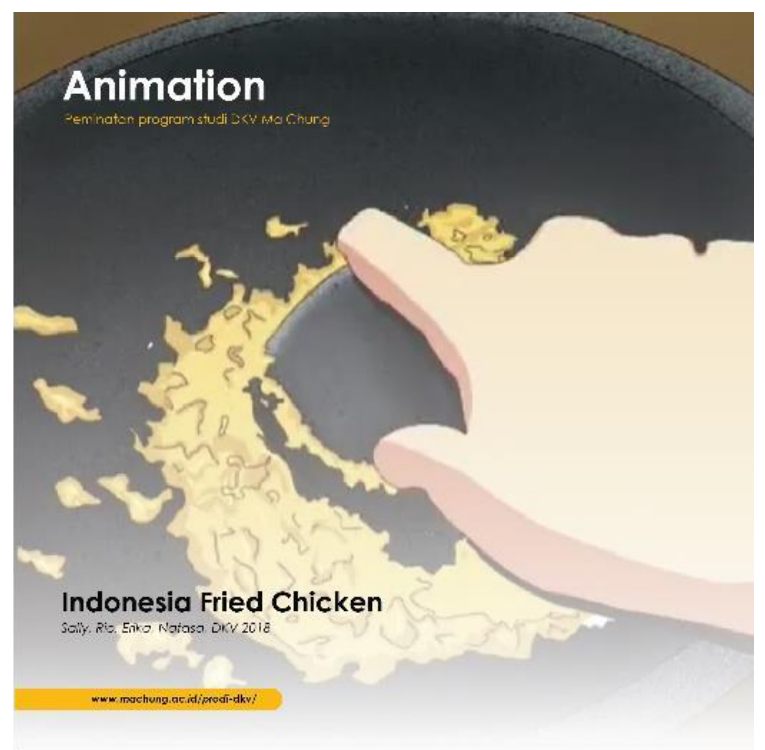

Games \& Digital Media Design

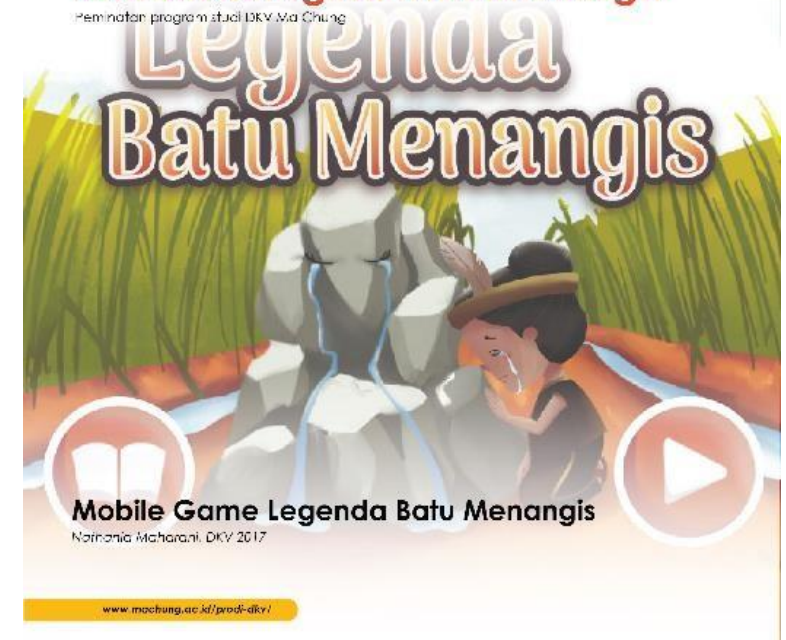

\section{Tau gak sih?}

Filosofi Logo DKV Ma Chung itu seperti apa?

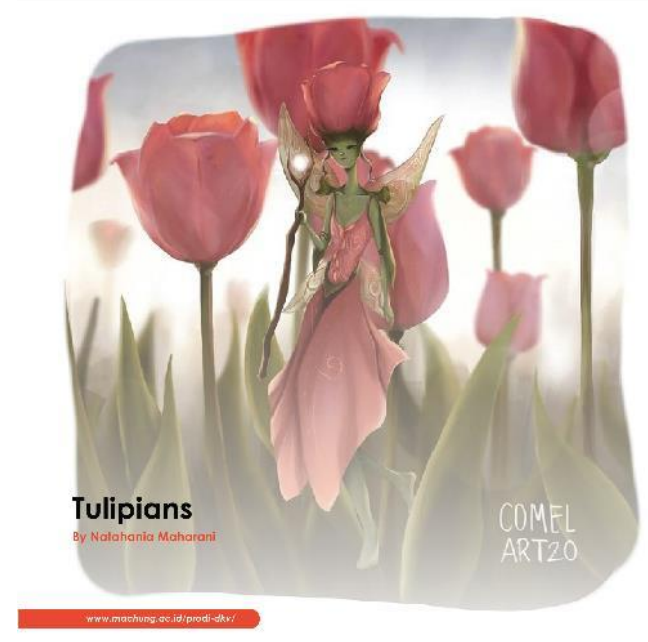

Gambar 11. Desain Feed Final 9

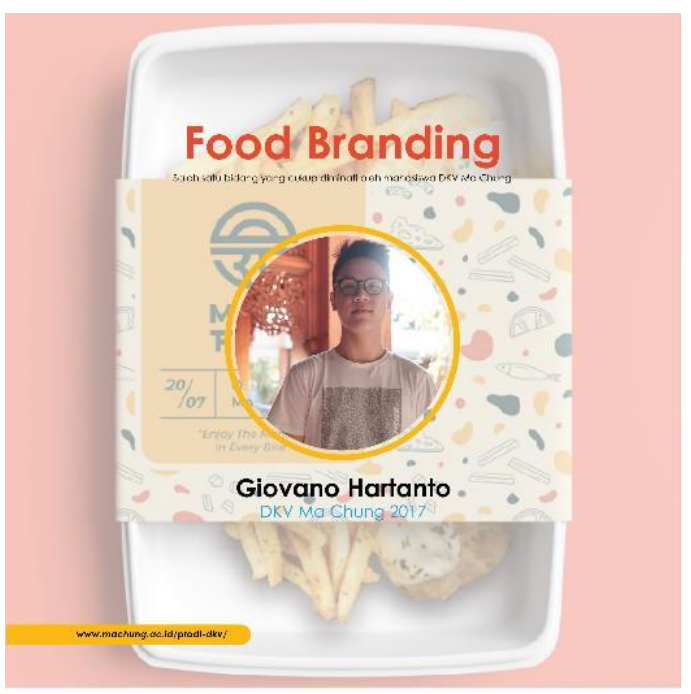


Gambar 10. Desain Feed Final 8

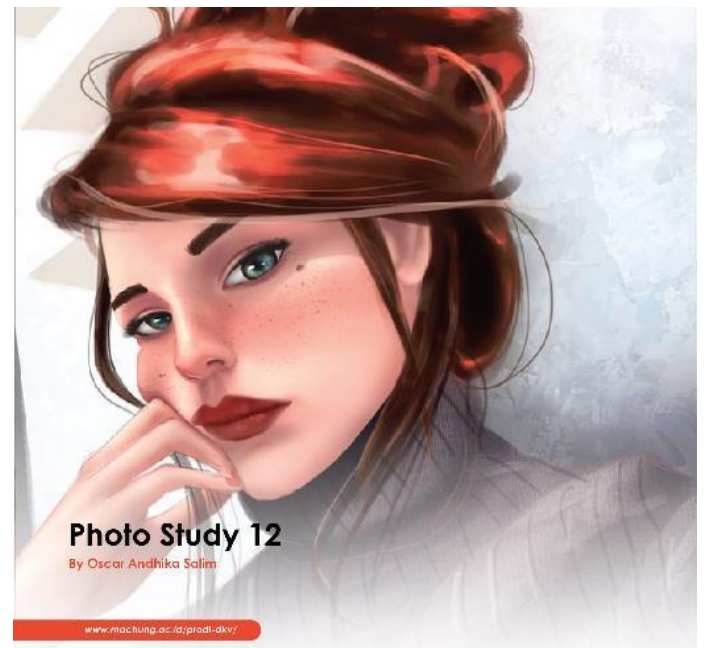

Gambar 12. Desain Feed Final 10

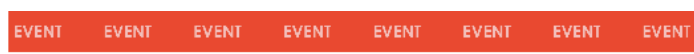

Udah pada tau belum?

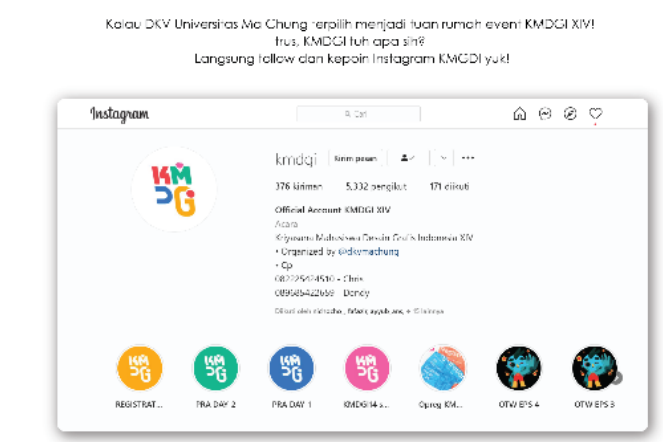

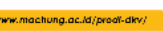

"Every great design begins with an even
better story."

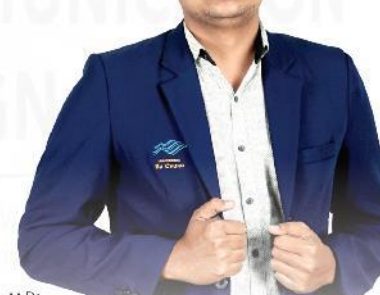

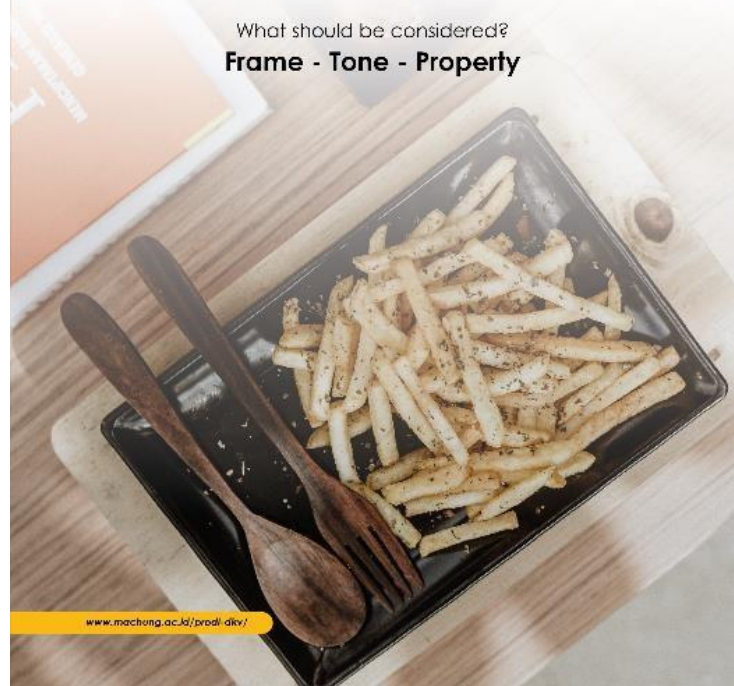

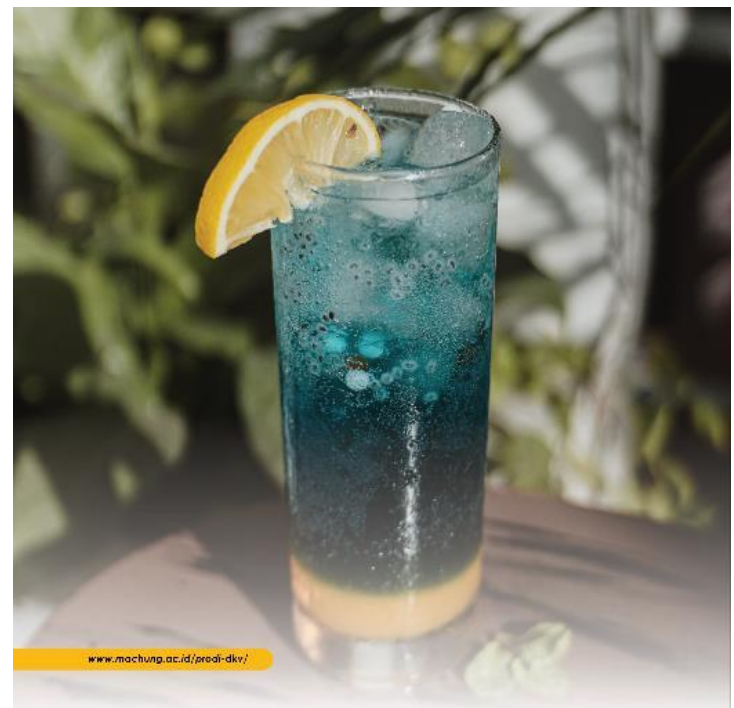

Gambar 14. Desain Feed Final 12

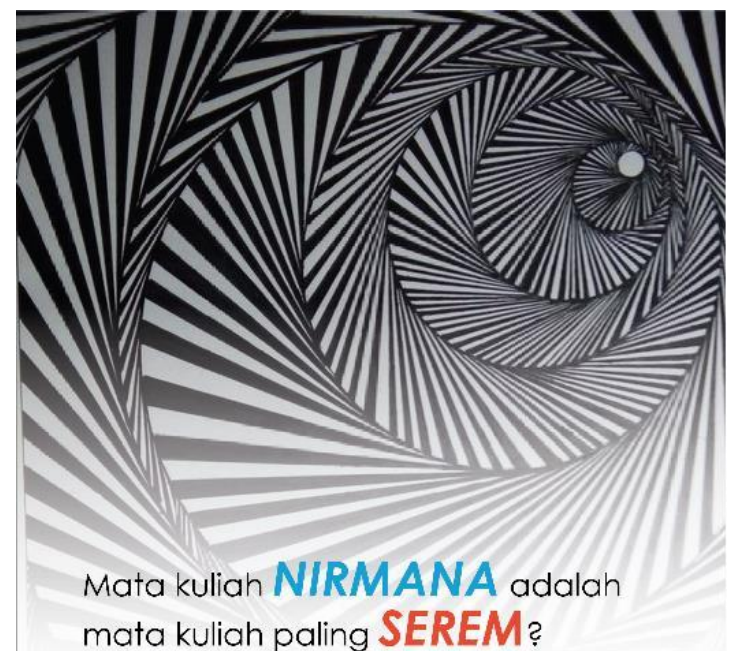

Mata kuliah NIRMANA adalah mata kuliah paling SEREM? 
Gambar 13. Desain Feed Final 11

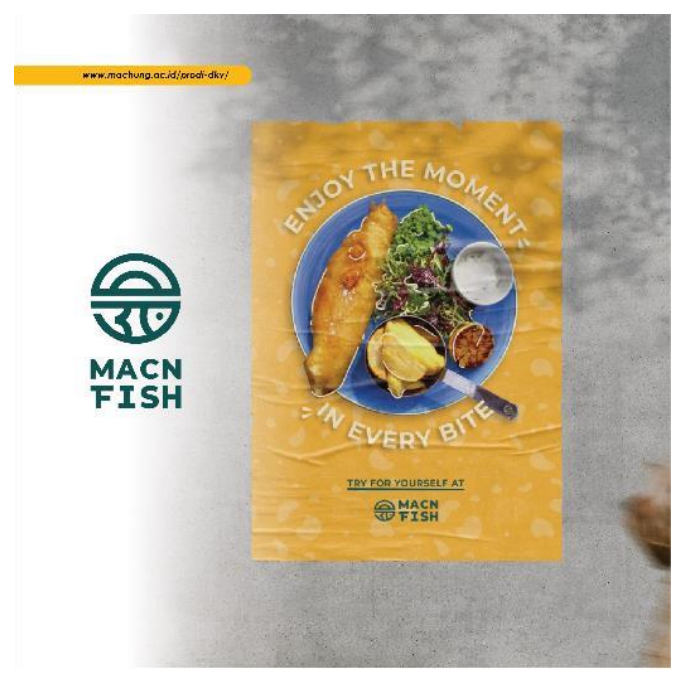

Gambar 15. Desain Feed Final 13

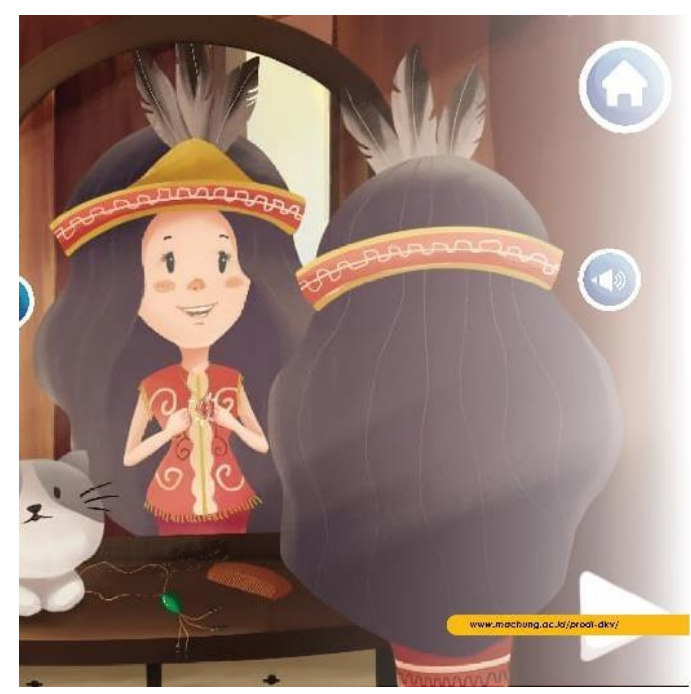

The Data.

Valid Information about History of beauty, skincare. and Make Up.

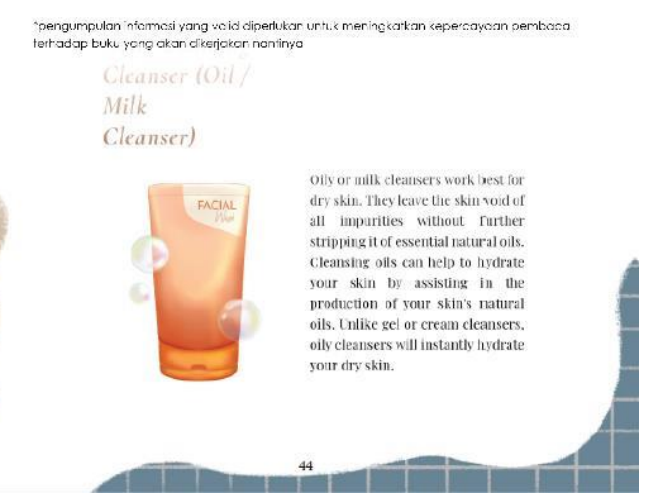

Gambar 16. Desain Feed Final 14

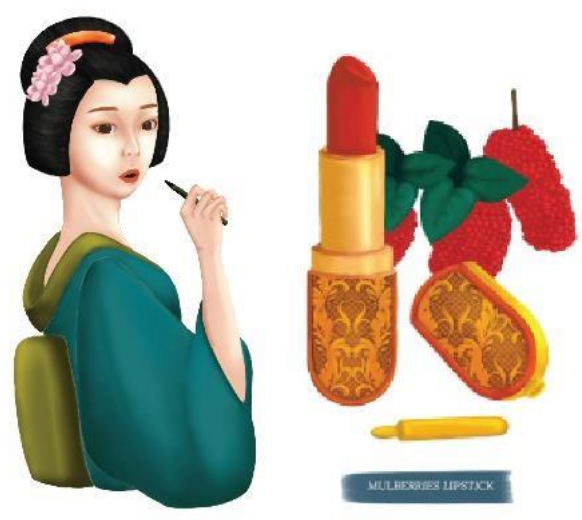

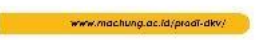

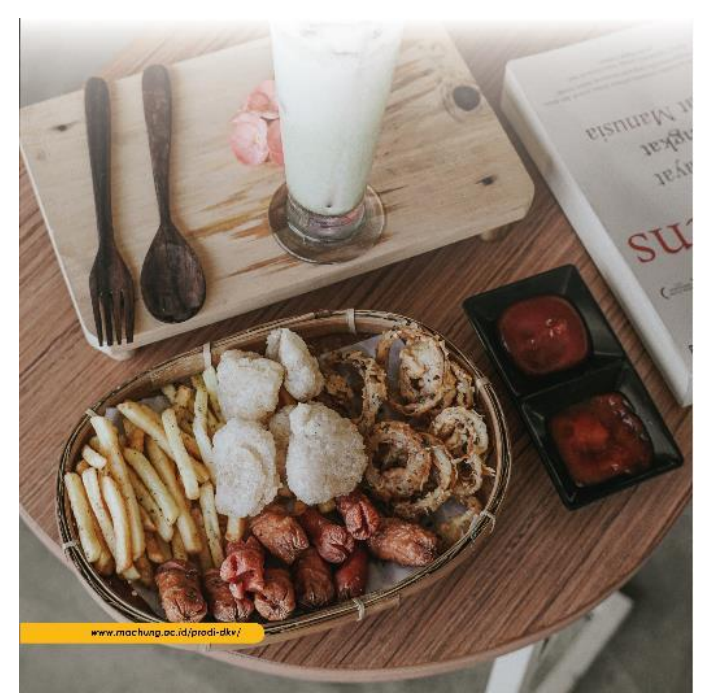

Gambar 17. Desain Feed Final 15 

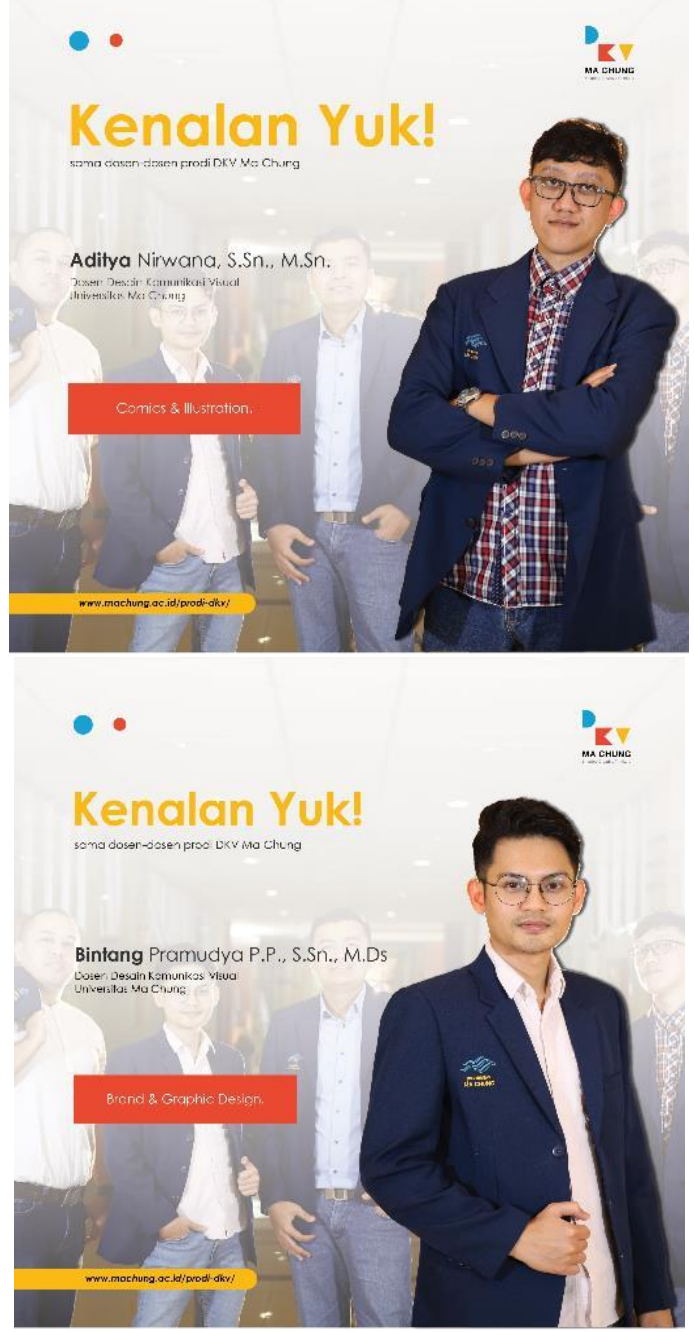

Gambar 19. Desain Feed Final 15

Desain Media Pendukung

Media pendukung merupakan karya luaran lain yang dapat menunjang daya tarik dari media utama sebagai luaran pokok. Pada perancangan ini, media utama adalah Desain Instagram Feed, sedangkan media pendukung berupa Instagram Filter, Totebag, Mug, Key chain.

\section{Instagram Filter}

Instagram filter merupakan salah satu fitur yang sangat diminati dan digunakan oleh banyak pengguna instagram karena fitur tersebut bersifat menyenangkan dan seru. Oleh karena itu dibuat media pendukung instagram filter dengan harapan pengikut instagram DKV Ma Chung dapat bersenang-senang dengan Filter yang sudah dibuat.

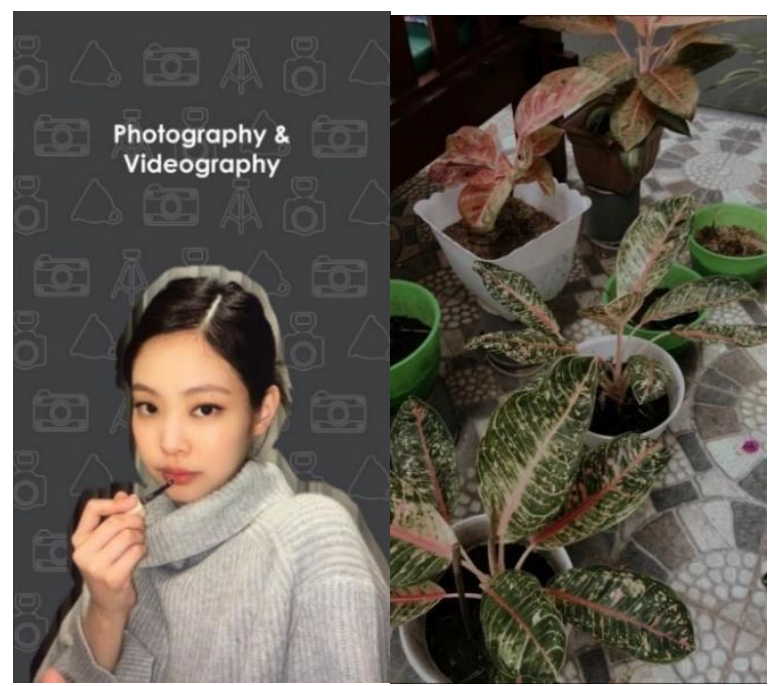

Gambar 13. Hasil Background Filter

\section{Totebag}

Totebag adalah salah satu jenis tas yang hampir selalu digunakan oleh mahasiswa DKV untuk meletakkan dan membawa alat-alat kesenian saat akan ke kampus. Oleh karena itu totebag menjadi salah satu media pendukung perancangan ini.

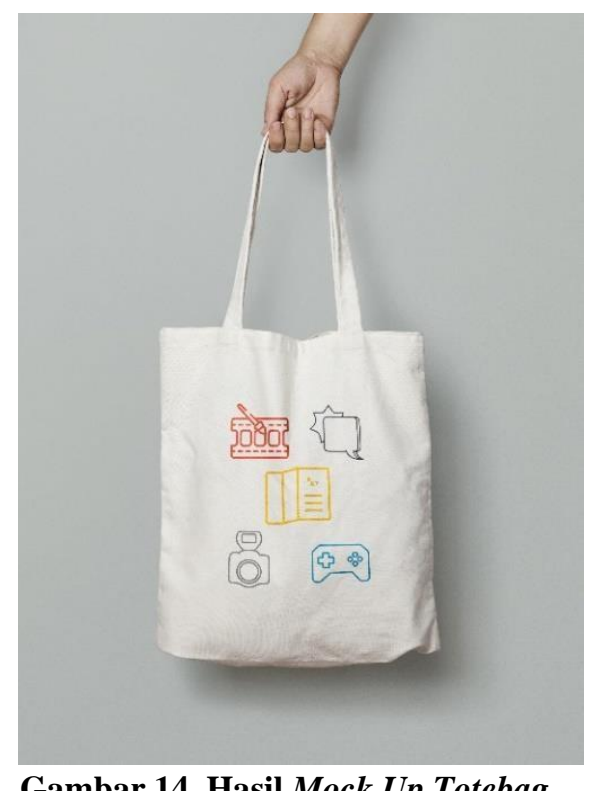

Mug

Mug adalah salah satu jenis gelas yang sering kali digunakan oleh banyak kalangan salah satunya yaitu mahasiswa dan dosen. Dosen biasanya membutuhkan mug untuk diletakkan di meja kerja sebagai alat minum atau sebagai tempat meletakkan stationary. 

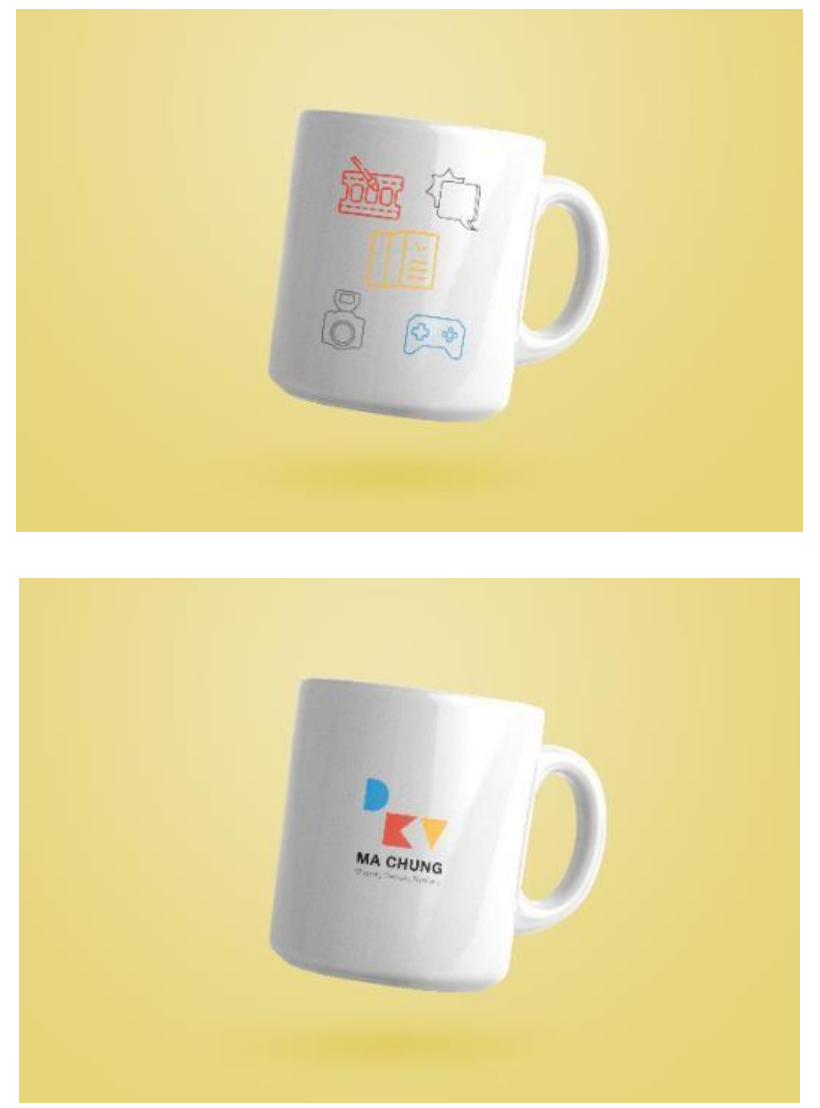

Gambar 15. Hasil Mock Up mug

Key Chain

Key Chain adalah salah satu jenis merchandise yang sangat umum. Key chain dapat digunakan sebagai pertanda bahwa pemilik keychain adalah salah satu dari bagian apa yang terdapat di keychain tersebut, misalnya komunitas, hobby, idola, dll. Oleh karena itu merch key chain dibuat agar mahasiswa dan dosen DKV Ma Chung memiliki sign atau belonging sebagai bagian dari DKV Ma Chung.

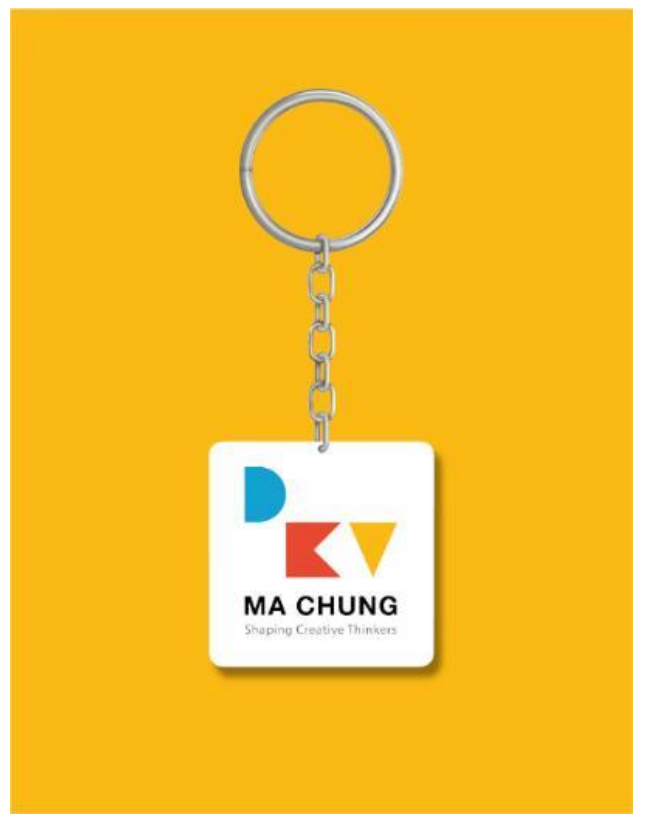

\section{Gambar 16. Hasil Mock Up Keychain}

\section{Penutup}

Bersosial media adalah salah satu kegiatan yang sudah sering dilakukan oleh manusia untuk tetap berkomunikasi tanpa harus bertemu. Social media juga digunakan untuk memperkenalkan, mempromosikan, dan menginformasikan sebuah jasa, produk, hingga instansi. Tapi tak semua media sosial dapat berjalan sesuai yang diharapkan seperti kenaikan jumlah pengikut dan kenaikan insight atau capaian pengguna media sosial yang lain. Dengan menciptakan desain yang baik dan konten yang menarik, dapat memenuhi tujuan daripada media sosial tersebut. Tentu saja dengan dibantu oleh sedikit digital marketing seperti Instagram Ads. Untuk saat ini Instagram termasuk salah satu media sosial yang sangat banyak digunakan oleh masyarakat di Indonesia bahkan di Dunia.

Instagram adalah media sosial yang menyediakan fitur feed untuk mengunggah foto, gambar, poster beserta kolom caption dan komentar. Fitur tersebut sudah dimanfaatkan oleh banyak pihak untuk mencapai tujuan dari sebuah perusahaan, lembaga, dll dalam menginformasikan segala hal yang sedang mereka kerjakan atau hal yang sedang terjadi. Berkat pengelolaan akun instagram yang baik dan tepat, hal tersebut dapat meningkatkan citra, penjualan, image, dll.

Tak hanya perusahaan, sebuah universitas pun juga membutuhkan media sosial dengan citra yang baik agar calon mahasiswa dan masyarkat di universitas dapat mengetahui apa saja yang sedang terjadi di lingkungan pendidikan yang sedang ditempuh. Contoh informasi yang biasa terdapat di media sosial sebuah universitas adalah informasi beasiswa, tanggal pendaftara, acara, dan lainlain. Tapi karena cakupan universitas cukup luas dan tentu saja terdapat banyak program studi didalamnya, alangkah baiknya jika terdapat instagram khusus untuk tiap program studi tersebut, agar informasi lebih terpilah dan tersaring.

Universitas Ma Chung adalah salah satu universitas yang memiliki citra akun instagram yang sangat baik dan modern. Di dalam Universitas Ma Chung terdapat salah satu program studi yang akan sangat menarik jika akun instagramnya dikelola menjadi konten yang kreatif dan menarik sehingga dapat menyampaikan isi dan informasi kepada pengikut instagram tersebut. Oleh karena itu dirancang lah konten kreatif media sosial Instagram

DKV Ma Chung.

Perancangan ini memiliki beberapa luaran yaitu berupa 40 desain instagram feed, video IGTV, dan beberapa media pendukung. Instagram feed diisi dengan informasi mengenai internal daripada DKV Ma Chung itu sendiri, seperti peminatan, visi misi, karya mahasiswa, hingga dosen-dosen DKV Ma Chung. Konten dikemas dan dikerucutkan menjadi beberapa segment sehingga mempermudah dalam pembuatan konten untuk selanjutnya. Terdapat pula media pendukung seperti filter instagram dan merchandise. 


\section{Saran}

Setelah melalui proses perancangan yang dilakukan untuk membuat Konten Kreatif pada media sosial instagram DKV Ma Chung, terdapat beberapa saran membangun agar perancangan serupa bisa menjadi lebih baik di masa yang mendatang. Saran ini ditujukan bagi peneliti selanjutnya, bagi Universitas Ma Chung, dan bagi para pengikut instagram DKV Ma Chung. Adapun saransaran tersebut adalah:

\section{Bagi Peneliti Selanjutnya}

Bagi para peneliti yang akan membuat perancangan serupa di masa mendatang diharapkan agar bisa menggali lebih dalam apa saja hal-hal yang terdapat pada DKV Ma Chung yang belum diketahui oleh masyarakat diluar sana, seperti bahwa "mahasiswa desain selalu begadang dan jarang tidur" untuk perancangan yang selanjutnya. Hal tersebut akan menarik perhatian pengikut mahasiswa DKV maupun non-DKV, karena mengungkap keseharian mahasiswa DKV itu seperti apa.

\section{Bagi Universitas}

Bagi universitas diharapkan untuk menggunakan media konsultasi online yang seragam antara pembimbing 1 dan 2. Hal ini dimaksudkan agar ketiga pihak (pembimbing 1, pembimbing 2, dan mahasiswa) memiliki kesepahaman yang sama terhadap media yang dirancang. Selain itu, model konsultasi online menggunakan media sosial juga dirasa cukup efektif untuk menyimpan data secara virtual sehingga bisa menjadi data cadangan bila terjadi hal yang tidak diinginkan.

\section{Bagi Pengikut Instagram}

Pengikut Instagram DKV Ma Chung diharapkan dapat menerima informasi yang kompleks mengenai seperti apa dan bagaimana kehidupan di DKV Ma Chung. Dan dengan harapan DKV Ma Chung dijadikan salah satu referensi untuk dijadikan tempat belajar atau perkuliahan bagi calon mahasiswa yang berminat dibidang seni dan desain.

\section{Daftar Pustaka}

Kotler, Philip \& Amstrong, Gary. (2008). Prinsip-Prinsip Pemasaran. Jilid 1 dan 2. Jakarta: Erlangga.

Alyusi. (2016). MEDIA SOSIAL: INTERAKSI, IDENTITAS, dan MODAL SOSIAL. Edisi Pertama. Jakarta: PRENADAMEDIA Group.

Nadhiro. (2019). Pengaruh Social Media Marketing Terhadap Brand Awareness Pada Followers Instagram Warunk Upnormal diakses pada 10 maret 2021. https://jurnalmahasiswa.unesa.ac.id/

Ulil Azmi, M. (2016). Pengaruh Program Komunikasi Pada Digital Marketing Dan Sales Promotion Terhadap Impulse Buying Pada Konsumen Situs Lazada.Co.Id. Program Studi Ilmu Komunikasi Falsafah Dan Peradaban Paramadina.
Saputra, D. (2020). Digital Marketing: Komunikasi Bisnis Menjadi Lebih Mudah.

Pratama, M. (2017). Pengaruh Digital Marketing dan Brand Awareness Terhadap Roses Keputusan Pembelian di Tokopedia.

Sanyoto, S. E.. (2006). Metode Perancangan Komunikasi Visual Periklanan, Dimensi Press, Yogyakarta, Indonesia.

Prastowo, A. (2011), Metode Penelitian Kualitatif Dalam Perspektif Rancangan Penelitian, Ar-Ruzz Media, Yogyakarta, Indonesia.

Maoyan et al. (2014). "Consumer Purchase Intentio Research Based on Social Media Marketing". International Journal of Business and Social Science. Vol. 5 No.10 (1), p 92-97. 


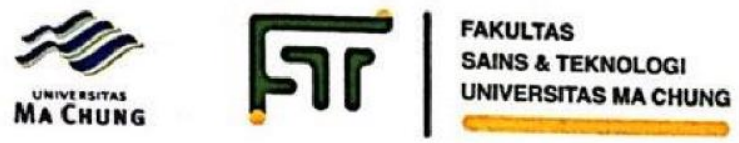

\section{PERNYATAAN PEMENUHAN SYARAT PUBLIKASI ILMIAH}

Saya yang bertanda tangan di bawah ini :

\begin{tabular}{|l|c|l|}
\hline Nama & $:$ & Nabila Ramadhani Zulfa \\
\hline NIM & $:$ & 331710015 \\
\hline Program Studi & $:$ & Desain Komunikasi Visual \\
\hline No. HP Aktif & $:$ & 082232069419 \\
\hline Email Ma Chung/OWA & $:$ & $331710015 @ s t u d e n t . m a c h u n g . a c . i d$ \\
\hline Email Non Ma Chung & $:$ & Nabilazulfa99@gmail.com \\
\hline Judul Tugas Akhir & $: \begin{array}{l}\text { PERANCANGAN KONTEN KREATIF BERBASIS MULTIMEDIA } \\
\text { UNTUK MENINGKATKAN AWARENESS PROGRAM STUDI } \\
\text { DESAIN KOMUNIKASI VISUAL UNIVERSITAS MA CHUNG } \\
\text { MELALUI MEDIA SOSIAL INSTAGRAM }\end{array}$ \\
\hline
\end{tabular}

bersama ini menyatakan dengan sesungguhnya bahwa saya telah LULUS Sidang Tugas Akhir dan berikut pernyataan tentang syarat publikasi ilmiah:

\begin{tabular}{|c|c|c|}
\hline \multicolumn{2}{|r|}{ Pernyataan ${ }^{*}$} & Keterangan \\
\hline & $\begin{array}{l}\text { 1. Sudah publikasi atau diterima untuk } \\
\text { publikasi pada Jurnal Ilmiah (Letter } \\
\text { of Acceptance atau LoA terlampir) }\end{array}$ & $\begin{array}{l}\text { Nama Jurnal : } \\
\text { Volume/Nomor/Tahun : } \\
\text { Judul Artikel : } \\
\text { Link Artikel: } \\
\end{array}$ \\
\hline & $\begin{array}{l}\text { 2. Sudah dikirimkan pada Jurnal Ilmiah } \\
\text { Eksternal (Email bukti pengiriman } \\
\text { artikel kepada redaksi jurnal } \\
\text { terlampir) }\end{array}$ & $\begin{array}{l}\text { Nama Jurnal: } \\
\text { Judul Artikel: } \\
\text { Status : masuk ke redaksi / proses review }\end{array}$ \\
\hline$\sqrt{ }$ & $\begin{array}{l}\text { 3. Sudah dikirimkan pada Jurnal IImiah } \\
\text { Internal Universitas Ma Chung } \\
\text { (Email bukti pengiriman artikel } \\
\text { kepada redaksi jurnal terlampir) }\end{array}$ & $\begin{array}{l}\text { Nama Jurnal : Artikel Ilmiah } \\
\text { Judul Artikel : Perancangan Konten Kreatif Berbasis } \\
\text { Multimedia Untuk Meningkatkan Awareness } \\
\text { Program Studi Desain Komunikasi Visual } \\
\text { Universitas Ma Chung Melalui Media Sosial } \\
\text { Instagram } \\
\text { Status : masuk ke redaksi I proses review }\end{array}$ \\
\hline$\sqrt{ }$ & $\begin{array}{l}\text { 4. Belum publikasi pada Jurnal limiah } \\
\text { menyerahkan artikel untuk dipublikasi } \\
\text { dengan / tanpa nama dosen pembimb } \\
\text { artikel terlampir) }\end{array}$ & $\begin{array}{l}\text { manapun (internal dan eksternal) dan } \\
\text { kan pada Repository Fakultas Sains dan Teknologi } \\
\text { ing sebagai author (hard copy dan soft copy }\end{array}$ \\
\hline & $\begin{array}{l}\text { 5. Belum publikasi pada Jurnal IImiah m: } \\
\text { karena Tugas Akhir saya adalah bagi }\end{array}$ & $\begin{array}{l}\text { lapun. Hak publikasi diambil alih dosen pembimbing } \\
\text { dari proyek penelitian dosen pembimbing }\end{array}$ \\
\hline
\end{tabular}

Saya menjamin bahwa naskah artikel ilmiah saya adalah asli, tidak melanggar hak cipta, hak milik atau hak lain apapun dari pihak manapun dan bahwa naskah tidak mengandung materi yang melanggar hukum, dan tidak membuat invasi yang tidak tepat dari privasi orang lain.

Demikian pernyataan-pernyataan ini dibuat dengan sebenarnya. Apabila di kemudian hari ditemukan adanya ketidakbenaran, saya bersedia menanggung akibat dan sanksi yang diberikan.

Malang, 10 Agustus 2021

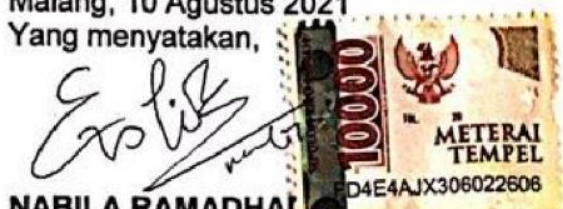

Mengetahui, 
